\title{
CORPORATE SOCIAL RESPONSIBILITY: KETERKAITAN LETAK GEOGRAFIS TERHADAP DESAIN PROGRAM DAN PELAPORAN PERUSAHAAN
}

\author{
Deasy Sagitaningrum \\ Universitas Surabaya \\ deasysagitaningrum@gmail.com \\ Dianne Frisko \\ Universitas Surabaya \\ dianne@staff.ubaya.ac.id
}

\begin{abstract}
This research aims to analyze the role of the geographical area surrounds company in the linkage with the design of corporate social responsibility (CSR) program and CSR reporting. This study uses qualitative approach by comparing two companies in different location. They are Indonesian companies (PT Indo Tambangraya Megah Tbk) and Australian company (OZ Minerals). Content analysis method is used to collect the public data. The result conveys factual information that the geographical area, natural environment, local value, and government policy create the differences for each company in designing the CSR program and the ways companies provide CSR report. Company which is located in cultural society are tend to design the CSR program by regarding the cultural values. Company which is located in certain jurisdiction tends to report CSR based on the regulated standard. Moreover, environment, education, health, and economic condition are also considered in designing CSR programs.
\end{abstract}

Keywords: geographic, CSR program, CSR reporting

\section{PENDAHULUAN}

Keterkaitan letak dan kondisi geografi dengan ekonomi dalam kehidupan sehari-hari sangat erat, karena setiap manusia melakukan interaksi baik dalam hubungan antar sesama manusia, dengan alam, maupun dengan makhluk hidup yang lain. Kondisi geografis diyakini memengaruhi nilai budaya masyarakat, pekerja, konsumen, pelaku bisnis dan kaum professional, termasuk juga kebijakan yang diambil pemerintah. Interaksi geografi dengan ekonomi, politik dan sosiologi membentuk situasi tempat masyarakat tinggal dan bekerja (Griesse 2007). Setiap aktifitas perusahaan, baik aktifitas operasional maupun non operasional tidak terlepas dari lingkungan sekitar perusahaan, serta kegiatan operasional perusahaan bergantung pula pada kondisi geografis dan lingkungan (Christmann 2004 dan Carroll 2004). Perusahaan 
mendapat tekanan dari stakeholder yang meliputi pelanggan, karyawan, investor serta masyarakat untuk mendemonstrasikan komitmen pada masyarakat dengan mengambil peranan dalam penanganan isu sosial dan lingkungan (Menguc dan Ozanne 2005). Dalam dua dekade terakhir, perusahaan-perusahaan menunjukkan komitmennya untuk mendukung terciptanya pembangunan berkelanjutan dengan menyeimbangkan orientasi perusahaan antara mengejar profit, dengan kepedulian terhadap masalah sosial dan lingkungan melalui praktik tanggung jawab sosial perusahaan. Kotler dan Lee (2005) menambahkan bahwa melakukan tanggung jawab sosial atau corporate social responsibility (CSR) merupakan komitmen untuk memperbaiki komunitas melalui praktik bisnis dan kontribusi sumber daya perusahaan.

CSR merupakan salah satu cara meningkatkan competitive advantage. Dentchev (2004) menemukan bahwa dukungan besar untuk perusahaan yang memberikan efek positif terletak pada hubungan dengan karyawan, klien, agen pemerintah dan masyarakat. Porter dan Kramer (2006) menunjukkan hubungan yang kuat antara kesejahteraan perusahaan dan masyarakat, dimana aktifitas CSR yang terintegrasi dengan baik dengan kegiatan bisnis inti, akan dapat membawa peluang, inovasi dan keunggulan kompetitif bersama dengan manfaat bagi masyarakat.

Dalam situasi persaingan dunia usaha, faktor lokasi menjadi hal kritis yang harus dipertimbangkan dengan baik oleh manajemen. Agar usaha yang dijalankan dapat bersaing secara efektif, lokasi strategis dan mudah untuk dijangkau menjadi komponen penting perusahaan (Choi et al., 2010). Alasan dibalik pemilihan lokasi perusahaan dimotivasi oleh tiga pertimbangan. Pertama, lokasi perusahaan berkaitan dengan kebijakan perusahaan dan proses pengambilan keputusan (John et al., 2010 serta Loughran 2008). Pemilihan lokasi dapat memengaruhi hasil perusahaan (Porter 2000), dan selanjutnya, perbedaan letak geografis menunjukkan hubungan positif dengan kinerja sosial perusahaan khususnya perusahaan multinasional (Brammer et al., 2006 serta Maignan dan Ralston 2002).

Beberapa penelitian telah menjelaskan hubungan antara lokasi perusahaan dan aktifitas sosial perusahaan (Wang dan Juslin 2009). Penelitian Scholtens dan Dam (2007) menemukan efek dari perbedaan geografis, tata kelola praktik korupsi, serta kebijakan hak asasi manusia. Brammer et al. (2006) serta Maignan dan Ralston (2002) menemukan hasil yang sama pada perusahaan-perusahaan besar Amerika Serikat dan tiga negara Eropa, tentang keterkaitan geografis dengan kinerja sosial perusahaan. Sementara itu Boeprasert (2012a) mengungkap keterkaitan lokasi perusahaan dengan kegiatan investasi dan CSR.

Sebagian besar penelitian yang telah dilakukan sebelumnya membahas keterkaitan letak geografis perusahaan terhadap aktifitas dan program CSR (Cheah et al. 2011 serta Wang dan Juslin 2009), dalam lingkup satu negara maupun satu 
benua. Sejauh ini, penelitian yang menunjukkan pengaruh letak geografis perusahaan terhadap model pelaporan CSR masih minim. Penelitian ini bertujuan membahas research gap tersebut, untuk mengetahui sejauh mana keterkaitan antara letak geografis terhadap desain program dan pelaporan CSR dengan mengambil studi kasus pada dua perusahaan di dua lokasi berbeda yang meliputi perbedaan benua, bangsa, tata kelola, bahasa serta budaya masyarakat sekitarnya.

Penelitian ini akan menganalisis lebih jauh keterkaitan letak geografis perusahaan dan faktor-faktor spesifik lain terkait geografis, dengan penerapan program tanggung jawab sosial perusahaan (CSR ). Selanjutnya, penelitian ini juga mengkaji bagaimana unsur geografis menjadi pertimbangan dalam format pelaporan yang disajikan perusahaan tentang aktifitas $C S R$, sehingga rumusan masalah yang menjadi bahan utama analisis penelitian ini dituangkan dalam bentuk pertanyaan penelitian (research question) berikut: (1) bagaimana kebijakan dan pelaksanaan program CSR di perusahaan?; (2) sejauh mana letak geografis dan faktor terkait geografis perusahaan menjadi pertimbangan dalam desain program CSR?; (3) bagaimana model pelaporan CSR di perusahaan?; (4) sejauh mana keterkaitan peran faktor-faktor geografis terhadap pelaporan CSR perusahaan?

Hasil penelitian ini diharapkan dapat memberi kontribusi teoretis terkait perkembangan teori akuntabilitas perusahaan dalam bentuk pelaporan atas aktifitas tanggung jawab sosial kepada stakeholder. Penelitian ini menunjukkan dimensi baru di bidang akuntansi terkait pelaporan dan akuntabilitas perusahaan mengenai faktor-faktor yang dipertimbangkan perusahaan dalam menyajikan pelaporan aktifitas sosial dan lingkungan. Dalam hal ini analisis keterkaitan letak geografis dan faktor-faktor yang melekat dengan kondisi geografis seperti kondisi sosial ekonomi dan nilai budaya masyarakat menjadi pertimbangan perusahaan dalam menyusun program sampai dengan pelaporan corporate social responsibility. Manfaat praktis yang dapat diperoleh dari penelitian ini, dapat memberi masukan dan menjadi contoh bagi perusahaan lain dalam menyusun program CSR agar lebih tepat sasaran, bermanfaat serta jelas pelaporannya.

\section{TELAAH PUSTAKA}

CSR merupakan wujud kepedulian perusahaan terhadap ekonomi, sosial dan lingkungan sesuai prinsip triple bottom line yang meliputi profit, people dan planet. Profit bertujuan pada hasil yang diinginkan perusahaan agar dapat terus beroperasi dan berkembang. People merupakan salah satu jaminan kelangsungan hidup perusahaan, dimana perusahaan harus memiliki kepedulian terhadap kesejahteraan karyawan dan masyarakat. Planet merupakan kepedulian terhadap lingkungan hidup dan keberlanjutan keragaman hayati yang ada pada lingkungan sekitar perusahaan (Elkington 1998). 
Tiga alasan perusahaan melakukan CSR menurut Bhatt (2002) adalah kepatuhan (compliance) terhadap peraturan, ketentuan hukum, kesepakatan, konvensi ataupun standar nasional maupun internasional yang berlaku tergantung pada luas skala perusahaan. Semakin besar skala perusahaan, maka peraturan yang diikuti mengacu skala internasional. Berikutnya adalah meminimalkan risiko (risk minimization), perusahaan harus menyadari dampak nyata dan dampak potensial secara sosial, ekonomi, politik maupun lingkungan. Motivasi lainnya adalah menciptakan nilai (value creation) yang dalam hal ini yaitu menciptakan "positive social value" dengan melibatkan masyarakat. Program penciptaan nilai tersebut dapat melalui inovasi investasi sosial (innovative social investment), konsultasi dengan stakeholders, dialog kebijakan (policy dialogue) dan membangun istitusi masyarakat (building civic institution) baik secara mandiri ataupun bersama perusahaan lain.

Pandangan yang lebih komprehensif mengenai CSR yang kemudian disebut sebagai teori "piramida CSR " dikemukakan oleh (Carol 1991 dalam Shahin 2007) bahwa tanggung jawab sosial perusahaan dapat dilihat berdasarkan empat jenjang yang merupakan satu kesatuan. Untuk memenuhi tanggung jawab ekonomis, sebuah perusahaan harus menghasilkan laba sebagai fondasi untuk mempertahankan perkembangan dan eksistensinya. Jenjang pertama adalah economic responsibility yang berkaitan dengan menyediakan ROI (return on investment) kepada pemegang saham, menciptakan pekerjaan dan pengupahan yang adil, menemukan sumber daya baru, mempromosikan penggunaan teknologi lanjutan, inovasi dan menciptakan barang dan jasa yang baru. Jenjang ke dua adalah Legal Responsibility yang berkaitan dengan peran perusahaan dalam memainkan peran sesuai dengan peraturan dan prosedur. Masyarakat mengharapkan agar perusahaan dapat memenuhi visi dan misi yang diusungnya. Selanjutnya adalah ethics responsibility, dimana pelaku bisnis diharapkan agar mempunyai moral serta etika kerja sesuasi dengan dimana perusahaan berada. Etika tidak harus sesuai dengan apa yang diatur dalam aturan formal, tetapi dapat memenuhi harapan masyarakat terhadap perusahaan, misalnya menghargai masyarakat, menghindari pencideraan masyarakat, dan mencegah adanya bencana bagi masyarakat. Jenjang terakhir adalah philanthropic responsibility yang berkaitan dengan harapan agar kegiatan yang dilakukan membawa manfaat kembali kepada masyarakat.

\section{Desain Program CSR}

Anatan (2008) menunjukkan adanya sembilan program kerja yang dapat dilakukan perusahaan dalam melaksanakan kegiatan tanggung jawab sosialnya. Program tersebut melibatkan stakeholders perusahaan baik internal maupun eksternal, baik people maupun planet. Program yang berkaitan dengan people adalah employee program, customer program dan supplier program dimana karyawan, konsumen dan pemasok merupakan bagian penting dari perusahaan yang dapat memengaruhi laba perusahaan secara langsung. Perusahaan dapat 
melakukan program community and broader society, dengan melakukan community development yang intinya membantu individu, kelompok komunitas dalam berusaha mengontrol kehidupan mereka sendiri dan mengusahakan untuk membentuk masa depan sesuai dengan keinginan mereka (Shardlow 1998 dalam Ambadar 2008).

Keseluruhan tahap pelaksanaan CSR perusahaan yang meliputi perencanaan, implementasi, evaluasi serta pelaporan harus dilakukan dengan baik dan teliti. Saat mendesain program CSR, strategi pelaksanaan harus ditetapkan dengan matang mulai dari menentukan target capaian, dana yang dialokasikan, hingga pengambilan keputusan aktifitas CSR seperti apa yang akan dilaksanakan untuk berapa lama, termasuk pihak yang terlibat (meliputi kerjasama dengan media, event management, pihak yayasan, LSM dan lainnya). Selain itu perlu dibuat antisipasi dan solusi atas hambatan yang mungkin terjadi di tengah pelaksaan program (Wibisono 2007). Desain awal program CSR perusahaan merupakan acuan utama perusahaan dalam menjalankan program $C S R$, serta dalam menentukan keberhasilan pelaksanaan program (Hazlett et al., 2007)

\section{Pelaporan CSR}

Selain program $C S R$, hal yang terpenting adalah bagaimana perusahaan melaporkan program CSR sebagai bentuk pertanggungjawaban dan alat komunikasi terhadap stakeholder bahwa program CSR sudah dijalankan secara nyata (Golob dan Bartlett 2007). Berbagai alasan perusahaan dalam melakukan pengungkapan informasi CSR secara sukarela adalah untuk menaati peraturan yang ada, untuk memperoleh keunggulan kompetitif melalui penerapan CSR yang memenuhi ekspektasi masyarakat, untuk melegitimasi tindakan perusahaan dan untuk menarik investor (Sayekti dan Wondabio 2008).

Pengungkapan CSR merupakan bagian dari akuntansi pertanggungjawaban sosial yang mengkomunikasikan informasi sosial kepada stakeholder. Menurut Guthrie dan Parker (1990) dalam Sayekti dan Wondabio (2008), pengungkapan informasi CSR dalam laporan tahunan merupakan salah satu cara perusahaan membangun, mempertahankan dan melegitimasi kontribusi perusahaan dari sisi ekonomis dan politis. Selain itu, CSR dapat memberikan informasi mengenai sejauh mana perusahaan memberikan kontribusi positif maupun negatif terhadap kualitas hidup manusia dan lingkungannya (Cheng 2011).

Salah satu panduan pelaporan CSR bagi perusahaan yang telah dikenal cukup luas adalah pedoman laporan keberlanjutan Global Reporting Initiative (GRI), yaitu praktek pengukuran, pengungkapan dan upaya akuntabilitas kinerja organisasi dalam mencapai tujuan pembangunan berkelanjutan kepada para pemangku kepentingan baik internal maupun eksternal. Laporan keberlanjutan yang disusun berdasarkan kerangka pelaporan Global Reporting Initiative (GRI) 
mengungkapkan keluaran dan hasil yang terjadi di periode laporan tertentu dalam konteks komitmen organisasi, strategi dan pendekatan manajemennya.

\section{Letak dan Kondisi Geografis dalam Aktifitas CSR}

Pemilihan program CSR oleh perusahaan akan bervariasi, hal ini terkait dengan letak geografisnya (Wang dan Juslin 2009). Beberapa penelitian terbaru menyatakan beberapa faktor spesifik memainkan peran penting dalam menjelaskan perbedaan kondisi geografis dengan aktifitas CSR. Faktor-faktor tersebut meliputi kondisi alam, budaya dan karakteristik demografi masyarakat sekitar (Cheah et al., 2011; Jamali dan Mirshak 2007; Wang dan Juslin 2009). Boeprasert (2012b) yang melakukan penelitian di pasar Amerika menemukan bahwa kedekatan geografis kantor pusat dengan wilayah metropolitan dapat memengaruhi tingkat CSR perusahaan tersebut. Diversifikasi geografis memainkan peran penting bahwa perusahaan menggunakan kebijakan dengan membentuk strategi kinerja sosial pada profil geografis mereka. Brammer et al. (2006) mengungkapkan bahwa perusahaan yang aktifitasnya tersebar di banyak negara memiliki kinerja sosial lebih unggul dibandingkan dengan perusahaan-perusahaan yang aktifitasnya lebih sempit secara geografis.

Hasil beberapa penelitian juga menemukan bahwa perbedaan letak geografis akan memengaruhi sistem pengungkapan CSR dari perusahaan tersebut. Hasil penelitian Boeprasert (2012b), menyatakan bahwa perusahaan di area pedesaan memberikan kualitas pengungkapan yang lebih baik dari perusahaan yang beroperasi di tengah kota. Hal berbeda diungkapkan oleh Golob dan Barlett (2007) yang melakukan penelitian di Australia dan Slovenia, yang mengungkapkan bahwa ada beberapa tekanan pasar pada badan usaha untuk mengadopsi pelaporan CSR . Penelitian yang dilakukan Waagstein (2011) mengungkap bahwa CSR adalah konsep fleksibel yang penerapannya dapat didasarkan pada intepretasi tiap negara, dalam hal ini negara dan regulasi yang dibuatnya. Sejalan dengan hal ini, Hooghiemstra (2000) juga mengungkap bahwa salah satu faktor yang memengaruhi pelaporan CSR adalah kondisi negara beserta aturannya.

\section{METODA PENELITIAN}

Penelitian ini merupakan qualitative research dengan pembahasan studi kasus pada objek penelitian dua perusahaan di industri tambang dengan lokasi yang berbeda. Pengumpulan data dilakukan melalui content analysis, yaitu mengambil data dan informasi yang tersaji di media publik. Objek penelitian ini adalah PT Indo Tambangraya Megah Tbk (ITM) dan OZ Minerals (OZM) yang terletak di dua negara yang berbeda yaitu Indonesia dan Australia. Alasan menggunakan perusahaan pertambangan karena kegiatan penambangan secara langsung memberi dampak pada alam dan sumber utama produk perusahaan tambang dipengaruhi letak geografis, kondisi dan kekayaan alam yang ada. 
Dipilihnya dua perusahaan yang berada di benua berbeda sebagai obyek penelitian agar terlihat jelas perbedaan letak geografis dan faktor-faktor geografis yang ada di dalamnya. Perbedaan letak geografis perusahaan yang berada di benua Asia dan Australia menunjukkan perbedaan faktor geografis yang memengaruhi, meliputi perbedaan kondisi alam, musim, cuaca, pola hidup masyarakat sekitar, peraturan pemerintah, hingga budaya yang ada di dua wilayah tersebut menunjukkan perbedaan. Faktor-faktor tersebut yang akan menjadi acuan untuk melakukan penelitian ini. Penelitian ini akan mengkaji lebih jauh keterkaitan faktorfaktor geografis dengan penerapan dan pelaporan aktifitas tanggung jawab sosial perusahaan.

Data dan informasi sebagai sumber analisis dua perusahaan diperoleh dari website masing-masing perusahaan, juga public domain yang menyajikan informasi terkait kebijakan, aturan, program CSR di masing-masing negara, maupun informasi dari media publik meliputi majalah, surat kabar, buletin, dan sumber lain yang relevan dan andal. Pengumpulan data dan informasi dengan metoda ini menggunakan kata kunci (keywords) untuk melakukan seleksi pada data yang relevan.

Data yang dikumpulkan, kemudian diseleksi dan disesuaikan dengan rumusan permasalahan yang dibahas dalam penelitian ini, serta dilakukan pemeriksaan silang antara sumber data yang satu dengan sumber lain. Data yang digunakan dalam pembahasan dan analisis meliputi data gambaran masing-masing perusahaan, kebijakan sektor industri pertambangan di kedua negara serta kondisi geografis kedua negara. Data lain terkait penerapan program CSR perusahaan meliputi latar belakang CSR, kebijakan CSR, jenis program CSR, informasi kondisi budaya masyarakat sekitar area geografis kedua perusahaan dan data lain yang relevan.

\section{HASIL DAN PEMBAHASAN}

PT Indo Tambangraya Megah Tbk (ITM) merupakan produsen batubara terkemuka di Indonesia yang memproduksi dan memasok batubara kelas premium untuk pasar lokal dan internasional selama lebih dari satu dekade. ITM memiliki lokasi eksplorasi di area Kalimantan yaitu di Bontang, Kutai Timur dan Kutai Kartanegara. Kondisi geografis pulau terbesar di Indonesia ini 40 persennya berupa hutan tropis yang juga mendapat julukan sebagai paru-paru dunia. Area Kalimantan Timur merupakan wilayah pertambangan batubara yang besar di Indonesia.

Sementara OZ Minerals (OZM) merupakan perusahaan tambang tembaga dan emas yang membuka area eksplorasi di Coober Pedy, Australia Selatan. Kondisi geografis Coober Pedy seluruhnya berupa daerah gurun di Australia dengan 
rata-rata suhu sehari-hari mencapai 40 derajat Celcius, dan kota ini adalah bagian paling kering di Australia (Detik 2013).

\section{Kebijakan dan Pelaksanaan Program CSR di Perusahaan}

Desain program CSR PT Indo Tambangraya Megah Tbk di pulau Kalimantan lebih memfokuskan pada program-program yang mengutamakan pemberdayaan masyarakat dan pendidikan yang ada di Kalimantan. Ragam kegiatan CSR ini disusun untuk turut berkontribusi dalam membantu mengatasi permasalahan sosial yang kerap dihadapi masyarakat yang meliputi masalah pendidikan, kesehatan, dan kondisi ekonomi yang rata-rata berada di garis kemiskinan. Berdasarkan data BPS (2007), penduduk miskin di wilayah Kalimantan Timur berjumlah 10 persen dari total penduduk. Adapun visi ITM adalah menjadi perusahaan yang berkomitmen memberdayakan masyarakat melalui kemitraan, kerja sama yang berkelanjutan menuju kemandirian dan meningkatkan taraf hidup masyarakat. Salah satu program CSR ITM adalah kepedulian pada dunia pendidikan dengan membina beberapa sekolah dan guru melalui pemberian fasilitas yang memadai untuk proses belajar mengajar.

Kondisi PT Indo Tambangraya Megah Tbk berbeda dengan OZ Minerals yang menambang di wilayah Coober Pedy, Australia Selatan. Kondisi wilayah sekitar OZ Minerals berupa gurun pasir. Wilayah tersebut memiliki penduduk yang sebagian besar adalah karyawan perusahaan. Kondisi ini juga menjadi pertimbangan perusahaan dalam mendesain program CSR. OZM mengutamakan programprogram yang bermanfaat bagi karyawan tambang dan penduduk sekitar daerah tambang, yaitu kontribusi dalam menjaga keselamatan dan kesehatan karyawan dan masyarakat sekitar dengan memberikan fasilitas kesehatan yang memadai mengingat minimnya fasilitas kesehatan di daerah sekitar lokasi tambang. Selain itu, OZ Minerals juga berkontribusi dalam bidang sosial melalui kerjasama dengan perusahan-perusahaan lokal dan memberikan pelatihan dan pembelajaran khusus bagi karyawan serta masyarakat sekitar. Program tersebut misalnya, bekerja sama dengan toko roti lokal di daerah Coober Pedy untuk memasok roti bagi karyawan di wilayah tambang.

\section{Keterkaitan Letak Geografis dalam Desain Program CSR}

PT Indo Tambangraya Megah Tbk sangat memperhatikan faktor-faktor geografis di areanya dalam mendesain program CSR perusahaan. Kegiatan CSR perusahaan mendapat dukungan pemerintah dan komunitas setempat. Dua program utama ITM adalah Community Development dan ITM for Education, yang dikhususkan bagi masyarakat sekitar. Sebagian besar fasilitas pendidikan di Kalimantan masih tertinggal jika dibandingkan dengan fasilitas pendidikan yang ada di Jawa. Perusahaan berusaha untuk membantu memfasilitasi masyarakat untuk belajar, mulai dari anak-anak, remaja hingga dewasa. 
Beberapa program CSR perusahaan pada tahun 2010 meliputi pemberian beasiswa bagi 600 siswa, dan pada tahun 2010-2011 memberi pelatihan pada seluruh guru yang ada di tiga area pertambangan perusahaan yaitu Kutai Timur, Kutai Kartanegara dan Bontang. Desain program CSR yang dilaksanakan perusahaan tidak jauh dari faktor-faktor geografis yang ada di Kalimantan. Dalam upaya meningkatkan perekonomian masyarakat dan menekan angka kemiskinan misalnya, program usaha mandiri “teri Borneo”, pelatihan ketrampilan manikmanik khas Kalimantan, budidaya singkong gajah di lahan bekas tambang dan lainlain. Program-program CSR ini didesain juga untuk mengembangkan kekayaan daerah setempat.

Melalui program-program CSR yang diberikan, perusahaan turut berpartisipasi mewujudkan Millennium Development Goals (MDG) yang disesuaikan dengan keadaan lingkungan sekitar Kalimantan. Beberapa tujuannya yaitu menanggulangi kemiskinan dan kelaparan; mencapai pendidikan dasar untuk semua; mendorong kesetaraan gender dan pemberdayaan perempuan; menurunkan angka kematian anak; meningkatkan kesehatan ibu; memerangi HIV/AIDS, malaria dan penyakit menular lainnya; juga memastikan kelestarian lingkungan hidup dan mengembangkan kemitraan global untuk pembangunan. Program CSR perusahaan didesain dengan mengacu tercapainya tujuan tersebut.

Desain program CSR OZ Minerals, memiliki varian program seperti, Our People, Safety and Health, Community dan Environment. Program-program tersebut bertujuan membantu masyarakat dan lingkungan sekitar perusahaan. OZ Minerals yang beroperasi di wilayah paling kering di Australia, membuat perusahaan bekerja keras untuk berkontribusi pada lingkungan. Perusahaan bekerjasama dengan perusahaan-perusahaan lokal untuk menjadi supplier barang atau jasa bagi OZM. Sebagai contoh, mereka bekerjasama dengan perusahaan roti lokal CRUSTS. CRUSTS menyediakan roti bagi pegawai tambang selama lima hari dalam seminggu. Program kerjasama ini memberikan keuntungan bagi CRUSTS sebesar 40 persen dan karyawan tambang tidak perlu jauh-jauh memikirkan cara mendapatkan makanan karena lokasi yang cukup jauh dari pertokoan.

OZ Minerals juga menggandeng Royal Flying Doctor Service (RFDS). OZ Minerals melakukan hal ini karena lokasi pertambangan di Coober Pedy sangat jauh dari kota besar, dan sering mengalami kesulitan untuk pertolongan darurat saat terjadi kecelakaan di area tambang. OZ Minerals memilih menggandeng RFDS sebagai mitra yang dikenal profesional dalam menangani hal-hal semacam itu. Saat ini RFDS sudah memiliki 18 landasan di Australia Selatan. Kerjasama ini bermanfaat tidak hanya untuk karyawan di area pertambangan, namun juga penduduk sekitar yang membutuhkan bantuan medis. 


\section{Keterkaitan Faktor Geografis dengan Pelaporan CSR}

Dalam melaporkan kegiatan CSR nya, PT Indo Tambangraya Megah Tbk menyajikan dalam bentuk majalah yang diterbitkan setiap tiga sampai empat bulan sekali. Keputusan ITM untuk mengungkapkan kegiatan CSR nya melalui majalah karena beberapa alasan. Pertama, belum ada regulasi yang mengatur tentang pelaporan CSR di seluruh wilayah Indonesia. Alasan ke dua, tujuan penerbitan majalah CSR sendiri adalah sebagai media komunikasi kawasan binaan ITM karena kegiatan operasional perusahaan sebagian besar berada di wilayah Kalimantan dan perusahaan hanya melaksanakan kegiatan CSR nya di Kalimantan. Hal ini mendasari pertimbangan manajemen, bahwa majalah adalah media komunikasi yang tepat untuk berkomunikasi dengan masyarakat wilayah sekitar dan anak perusahaan.

Pengungkapan CSR dalam bentuk majalah tidak terlepas dari peran letak geografis ITM. Pengambilan nama majalah yaitu BUBUHAN yang diambil dari bahasa Kutai, Dayak dan Banjar yang berarti pertemanan, perkawanan atau persahabatan. Nama BUBUHAN mencerminkan semangat Community Development PT Indo Tambangraya Megah Tbk untuk selalu menghargai dan belajar pada kearifan lokal masyarakat. Selain itu, faktor terkait geografis tampak melalui informasi yang tersaji dalam majalah tersebut yang menampilkan kebudayaan Kalimantan dan sekitarnya. Seluruh program CSR yang telah dilakukan berkaitan dengan pelestarian kebudayaan seperti program binaan batik Sasirangan (batik khas Kalimantan), manik-manik dari batu-batuan yang hanya ada di Kalimantan, program binaan "teri Borneo" dan sebagainya. Edukasi tentang Kalimantan juga tak ketinggalan menjadi bahasan dalam majalah tersebut seperti tips merawat kain batik Sasirangan, pembahasan tentang rotan asal Kalimantan dan informasi bagi stakeholder lainnya. Melalui majalah ini juga disajikan informasi kegiatan, maupun informasi edukasi umum terkait topik ekonomi, sosial, kesehatan maupun pendidikan.

Pengungkapan aktifitas CSR melalui majalah lebih mudah dipahami oleh stakeholder, termasuk didalamnya masyarakat Kalimantan yang menjadi mitra binaan dari PT Indo Tambangraya Megah Tbk. Mereka akan mudah mengerti karena pengungkapan yang disajikan berupa foto-foto kegiatan disertai uraian bahasa yang mudah dimengerti. Perusahaan memilih majalah sebagai media berkomunikasi yang sesuai dengan masyarakat dan komponen stakeholder lainnya sebagai bentuk pelaporan dan pertanggungjawaban atas program-program CSR yang dilakukan.

Berbeda dengan Indonesia yang tidak menetapkan standar dalam pengungkapan CSR, Australia memiliki beberapa standar yang bisa dijadikan acuan, meskipun pelaporan CSR bagi perusahaan di Australia bersifat voluntary. Namun disisi lain, Corporations' Law menuntut perusahaan mengungkapkan 
kinerja lingkungan, sosial yang terkait dengan tata kelola perusahaan (Golob dan Bartlett 2007). Praktik pelaporan CSR di Australia terbentuk secara alami dengan mengacu pada standar global dan acuan standar pelaporan seperti Global Reporting Initiative (GRI) maupun AA 1000 dan United Nation Global Compact.

Kebijakan pemerintah Australia terkait acuan pelaporan kegiatan CSR bagi perusahaan yang berlokasi di wilayah negara Australia ini mendorong OZ Minerals untuk mengikuti tuntutan pemerintah Australia. Diantaranya yaitu pengungkapan sustainability performance dengan mengikuti standar internasional Global Reporting Initiative (GRI). Berdasar regulasi pemerintah Australia, maka perusahaan mengikuti acuan yang ditetapkan dan mengikuti indikator-indikator dalam aturan GRI.

\section{SIMPULAN}

Kegiatan CSR merupakan kegiatan sosial yang dilakukan perusahaan sebagai bentuk tanggung jawab sosial bagi stakeholder khususnya yang ada di sekitarnya. Hal ini mendukung penelitian yang dilakukan oleh Brammer et al. (2006) tentang hubungan kinerja perusahaan dan letak geografis. Penelitian ini mengungkap bahwa perusahaan tampak mempertimbangkan kondisi geografis, dimana perusahaan berada dalam tahap mendesain program hingga pelaksanaan program CSR. ITM menyesuaikan desain program dengan kondisi ekonomi dan sosial masyarakat yang tinggal di wilayah tambang berupa hutan dan jauh dari fasilitas pendidikan dan pemberdayaan ekonomi. Program-program CSR berbasiskan kebutuhan masyarakat yang tinggal dengan kondisi alam Kalimantan, telah dilakukan ITM sebagai bentuk tanggung jawab sosial kepada stakeholder. Hal ini juga tampak pada OZ Minerals, dimana kondisi geografis area tambang dan kebutuhan masyarakat sekitar tambang yang berupa gurun dan minim fasilitas kesehatan, menjadi pertimbangan utama bagi OZ Minerals dalam mendesain hingga akhirnya melaksanakan program CSR untuk memenuhi kebutuhan stakeholder sekitar area tambang Coober Pedy.

Komponen geografis lain yang membuat perusahaan berbeda-beda dalam memutuskan desain program CSR adalah kebudayaan dari sebuah wilayah itu sendiri. Perusahaan yang berada di wilayah geografis yang kental kebudayaannya, cenderung mempertimbangkan dan mendesain program CSR bagi masyarakat dengan memasukkan nilai-nilai budaya masyarakat melalui inisiatif pelestarian budaya dan peningkatan kualitas hasil produk budaya tersebut, termasuk juga pelatihan cara memasarkan hasil budaya masyarakat guna peningkatan kondisi ekonomi, pendidikan, dan kesehatan masyarakat. Konsep penerapan CSR yang memberi manfaat bagi stakeholder dapat diwujudkan melalui program peningkatan taraf hidup masyarakat sekaligus pelestarian budaya mereka. Letak Geografis berkaitan erat terhadap kondisi sosial masyarakat sekitar perusahaan. Perusahaan 
cenderung memberikan program CSR sesuai dengan kebutuhan masyarakat yang ada di sekitarnya.

Selain itu, penelitian ini juga mendukung penelitian yang dilakukan oleh Golob dan Bartlett (2007) mengenai beberapa tekanan pasar pada badan usaha untuk mengadopsi pelaporan CSR. Dalam melaporkan CSR, perusahaan cenderung menunjukkan sikap yang berbeda dalam memilih format pelaporan. Perusahaan di wilayah geografis tertentu melaporkan kegiatan CSR mereka menggunakan standar yang sudah diadopsi di negaranya. Disisi lain, beberapa negara yang belum menetapkan standar dalam pelaporan, membuat perusahaan lebih bebas dalam melaporan CSR dengan format yang lebih kreatif.

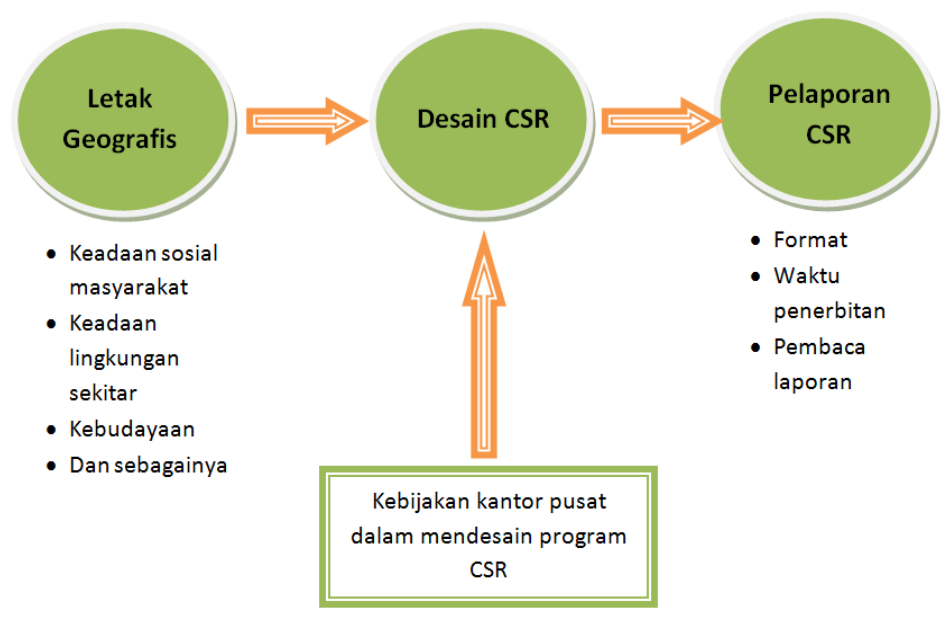

Gambar 1

Keterkaitan Letak Geografis, Desain Program dan Pelaporan CSR

Aspek kebudayaan juga berperan dalam penyusunan laporan CSR bagi perusahaan yang berada di wilayah geografis tertentu. Hasil penelitian ini menunjukkan PT Indo Tambangraya Megah Tbk menyajikan laporan aktifitas CSR dalam format majalah dengan nama yang diambil dari bahasa daerah setempat, dan diterbitkan secara periodik. Majalah CSR perusahaan ini tidak hanya berisi tentang program $C S R$, tetapi juga menjadi media edukasi tentang kebudayaan masyarakat sekitar. Dalam hal ini perusahaan juga turut melestarikan budaya masyarakat dan mengenalkan kebudayaan wilayah tersebut kepada banyak pihak, terutama pembaca laporan.

Dalam pembuatan laporan, keadaan sosial masyarakat sekitar menjadi hal yang perlu diperhatikan. Masyarakat dengan latar belakang yang beragam juga merupakan bagian dari stakeholder yang merupakan sasaran pembaca laporan CSR. Jika masyarakat tidak mampu memahami, maka akan menjadi sulit bagi perusahaan dalam menjalin komunikasi dengan masyarakat.

Hasil penelitian ini menemukan bahwa letak geografis berperan pada aktifitas CSR sebuah perusahaan, baik dalam mendesain maupun pelaporannya. Dalam letak geografis itu sendiri, terdapat banyak aspek yang perlu 
dipertimbangkan saat perusahaan membuat keputusan dalam mebuat desain program CSR. Seperti misalnya keadaan lingkungan sekitar, keadaan sosial masyarakat sekitar yang meliputi pendidikan, kesehatan, dan juga keadaan ekonomi masyarakat sekitar. Hal tersebut menjadi pertimbangan agar program CSR yang diberikan perusahaan tepat pada sasaran.

Hasil penelitian ini menunjukkan bahwa letak geografis berperan dalam upaya perusahaan mendesain program CSR untuk memenuhi kebutuhan stakeholder. Faktor lain yang lebih spesifik dan erat kaitannya dengan kondisi geografis yang meliputi aspek sosial, ekonomi dan budaya masyarakat serta kondisi lingkungan turut menjadi pertimbangan dalam penyusunan pelaporan CSR perusahaan. Secara teoretis penelitian ini memberi implikasi terkait faktor nonkeuangan yang meliputi aspek sosial dan lingkungan geografis dalam penyusunan dan penyajian pelaporan tanggung jawab sosial perusahaan.

Keterbatasan dari penelitian ini yang potensial untuk digali lebih dalam yaitu terkait lingkup objek studi kasus, yang menggunakan dua perusahaan tambang di dua negara berbeda, Indonesia dan Australia yang sudah mengeluarkan online report. Penelitian ini tidak mencakup perusahaan yang bergerak di bidang selain pertambangan dan tidak mencakup perusahaan yang tidak mengeluarkan online report. Fokus penelitian ini hanya terbatas pada letak geografis yang dikaitkan dengan desain program dan penyajian pelaporan terkait pelaksanaan CSR. Peluang penelitian berikutnya dapat dikembangkan dengan melihat keterkaitan antara lokasi perusahaan dan sistem pemerintahan yang lebih mendalam terhadap pelaporan CSR serta dapat dikembangkan pada lokasi dan jenis perusahaan yang berbeda.

\section{DAFTAR PUSTAKA}

Ambadar, J. 2008. Corporate Social Responsibility dalam Praktik di Indonesia. Jakarta: PT. Elek Media Komputindo Kelompok Gramedia.

Anatan, L. 2008. Corporate social responsibility (CSR): Tinjauan teoritis dan praktis di Indonesia. Jurnal Jurusan Manajemen Universitas Kristen Maranatha. Vol.8 No.2: 5.

Bhatt, M. 2002. Corporate Social Responsibility and Natural Disaster Reduction: Local Overview of Gujarat. DFID-funded study conducted by the Benfield Grieg Hazard Research Centre, University College London.

Boeprasert, A. 2012a. Does Location Matter for Corporate Social Responsibility?. National Institute of Development Administration (NIDA) and PTT Global Chemical (PTTGC). 
Boeprasert, A. 2012b. Does geographical proximity affect corporate social responsibility? Evidence from U.S. market. International Business Research. Vol.5 No.9.

Brammer, J. S., Stephen P., dan Porter L. A. 2006. Corporate social performance and geographical diversification. Journal of Business Research. Vol.59: 1025-1034.

BPS. 2007. BPS Provinsi Kalimantan Timur. Available at http://kaltim.bps.go.id.

Carroll A. B. 2004. Managing ethically with global stakeholders: A present and future challenge. Academy Management Executive. Vol.18 No.2: 114-120.

Cheah, E. T., Jamali, D., Johnson, J. E. V., dan Sung, M. C. 2011. Drivers of corporate social responsibility attitudes: the demography of socially responsible investors. British Journal of Management. Vol.22 No.2: 305-323.

Cheng, M., dan Y. J. Christiawan. 2011. Pengaruh pengungkapan CSR terhadap abnormal return. Jurnal Akuntansi dan Keuangan. Vol.13 No.1: 24-36.

Choi, J. S., Y. M. Kwak., dan C. Choe. 2010. Corporate social responsibility and corporate financial performance: evidence from Korea. Australian Journal of Management. Vol.35 No.3: 291-311.

Christmann, P. 2004. Multinational companies and the natural environment: determinants of global environmental policy standardization. Academic Management Journal. Vol.47 No.5: 747-60.

Dentchev, N. A. 2004. Corporate social performance as business strategy. Journal of Business Ethics. Vol.55 No.4: 395-410.

Detik. 2013. Coober Pedy Satu-Satunya Kota Bawah Tanah di Dunia. Available at http://m.detik.com/travel/read.

Elkington, J. 1998. Cannibals with Forks: The Triple Botom Line of $21^{\text {st }}$ Century Business, Philadelpia: New Society.

Golob, U., dan J. L. Bartlett. 2007. Communicating about corporate social responsibility: a comparative study of CSR reporting in Australia and Slovenia. Public Relation Review. Vol.33:1-9.

Griesse, M. A. 2007. The geographic, political, and economic context for corporate social responsibility in Brazil. Journal of Business Ethics. Vol.73: 21-37.

Hazlett, S. A., Mc Adam, dan L. Murray. 2007. From quality management to socially responsible organizations: the case for CSR. International Journal of Quality and Reliability Management. Vol.24 No.7: 669-682. 
Hooghiemstra, R. 2000. Corporate communication and impression management-new perspectives why companies engage in corporate social reporting. Journal of Business Ethics. Vol.27: 55-68.

Jamali, D., dan R. Mishak. 2007. Corporate social responsibility (CSR): theory and practice in a developing country context. Journal of Business Ethics. Vol.72 No.3: 243-362.

John, K., Knyazeva, A., dan Knyazeva D. 2010. Do shareholders care about geography?. Journal of Financial Economics. Vol.101 No.3: 533-551.

Kotler, P., dan N. Lee. 2005. Corporate Social Responsibility. New Jersey: John Wiley and Sons, Inc.

Loughran, T. 2008. The impact of firm location on equity issuance. Financial Management. Vol.37: 1-21.

Maignan, I., dan D. A. Ralston. 2002. Corporate social responsibility in Europe and the U.S.: insights from businesses' self-presentations. Journal of International Business Studies. Vol.33 No.3: 497-514.

Menguc, B., dan Ozanne L.K. 2005. Challenges of the 'green imperative': a natural resource based approach to the environmental orientation-business performance relationship. Journal Business Research. Vol.58:430-438.

Porter, M. E., dan M. R. Kramer. 2006. Strategy and society: the link between competitive advantage and corporate social responsibility. Harvard Business Review.

Porter, M. E. 2000. Location, competition and economic development: Local clusters in a global economy. Economic Development Quarterly. Vol.14 No.1: 15-34.

Scholtens, B., dan L. Dam. 2007.Cultural values and international differences in business ethics. Journal of Business Ethics. Vol.75: 273-284.

Shahin, A., dan M. Zairi. 2007. Corporate governance as a critical element for driving excellence in corporate social responsibility. International Journal of Quality and Reliability Management. Vol.24 No.7: 753-770.

Waagstein, P. R. 2011. The mandatory corporate social responsibility in Indonesia: problems and implication. Journal of Business Ethics. Vol.98: 455-466.

Wang, L., dan H. Juslin. 2009. The impact of Chinese culture on corporate social responsibility: the harmony approach. Journal of Business Ethics. Vol.88: 433-451.

Wibisono, Y. 2007. Membedah Konsep dan Aplikasi CSR. Gresik: Fascho Publishing. 
Wondabio, L. S., dan Y. Sayekti. 2008. Pengaruh CSR disclosure terhadap earning pada perusahaan yang terdaftar di Bursa Efek Jakarta). Jurnal Akuntansi dan Bisnis. Vol.8 No.2: 179-19. 